\title{
KEPATUHAN KONSUMSI TABLET BESI FOLAT PADA IBU HAMIL DAN FAKTOR YANG MEMPENGARUHI
}

\author{
Febriana Rahmawati, Hertanto Wahyu Subagio ${ }^{*}$ \\ Program Studi Ilmu Gizi Fakultas Kedokteran Universitas Diponegoro \\ Jl.Dr.Sutomo No.14, Semarang, Telp (024) 8453708, Email : gizifk@undip.ac.id
}

\begin{abstract}
Backgrounds : Anemia in pregnant women can effect maternal death, increased fetal morbidity and mortality. Iron supplementation programs should have a high success rate because the iron folate tablets are easily available and free of charge. But in reality. the compliance rate of iron folate tablets is still low

Purpose: analyze compliance rate of iron folate tablets in pregnant women at Puskesmas Halmahera and the factors influenced.

Method: An analytic observational research with cross-sectional design. The subjects in this study is 56 pregnant women who went on Puskesmas Halmahera. Subject was taken by consecutive sampling technique with the criteria pregnant women trimester 2 and 3. Compliance data, knowledge, education, family support and health care obtained through interviews with a questionnaire. Normality of data was tested using Kolmogorov-Smirnov. Bivariate analyzes performed using Rank Spearman test

Result: there is a association between knowledge scores with compliance $(r=0.370, p=0.005)$, there is no significant association between education level and compliance $(r=0.032, p=0.817$ there is no significant association between family support and compliance $(r=0.216, p=0.115)$ and there is no significant association between health service and compliance $(r=0.217, p=0.108)$

Conclusion: more than a half of respondents $(58,9 \%)$ did not comply consume iron folate tablets. Based on the data can be seen that the knowledge is the most influental factor.
\end{abstract}

Keywords : pregnant women; compliance; iron folate tablets; knowledge; education level; family support; health provider.

\section{ABSTRAK}

Latar belakang: Anemia pada wanita hamil dapat mengakibatkan kematian maternal, peningkatan angka kesakitan dan kematian janin. Program suplementasi besi seharusnya memiliki tingkat keberhasilan yang cukup tinggi mengingat tablet mudah diperoleh dan gratis. Namun pada kenyatannya banyak ibu hamil yang tidak patuh mengkonsumsinya.

Tujuan: menganalisis kepatuhan konsumsi tablet besi folat pada ibu hamil di Puskesmas Halmahera dan faktor yang mempengaruhi

Metoda: Penelitian ini merupakan penelitian deskriptif analitik yang dilakukan dengan menggunakan desain cross-sectional di Puskesmas Halmahera. Jumlah subyek dalam penelitian ini adalah sebesar 56 orang ibu hamil. Pengambilan subyek dilakukan dengan menggunakan teknik consecutive sampling dengan kriteria ibu hamil trimester 2 dan 3. Data kepatuhan, pengetahuan, tingkat pendidikan, dukungan keluarga dan kepuasan terhadap pelayanan kesehatan diperoleh melalui wawancara dengan kuesioner. Normalitas data diuji dengan Kolmogorov-Smirnov. Analisis bivariat dilakukan dengan menggunakan uji Rank Spearman

Hasil: adanya hubungan antara pengetahuan dengan kepatuhan $(r=0,370, p=0,005)$, tidak ada hubungan yang bermakna antara pendidikan dengan kepatuhan $(r=0,032, p=0,817)$, tidak ada hubungan bermakna antara dukungan keluarga dengan kepatuhan $(r=0,216, p=0,115)$ dan tidak ada hubungan bermakna antara pelayanan kesehatan dengan kepatuhan $(r=0,217, p=0,108)$

Simpulan: Lebih dari setengah jumlah responden (58,9\%) tidak patuh mengkonsumsi tablet besi folat. Berdasarkan data yang diperoleh dapat diketahui bahwa variabel pengetahuan menjadi faktor yang paling berpengaruh dibandingkan faktor yang lainnya.

Kata Kunci : ibu hamil; kepatuhan; tablet besi folat; pengetahuan; pendidikan; dukungan keluarga; pelayanan kesehatan.

\section{PENDAHULUAN}

Anemia merupakan salah satu masalah yang cukup sering terjadi terutama di negara-negara yang sedang berkembang. Hal tersebut tidak berbeda dengan yang terjadi di Indonesia dimana anemia masih menjadi masalah

${ }^{*}$ Penulis Penanggungjawab 
yang belum dapat diatasi hingga saat ini. ${ }^{1}$

Menurut data WHO (2005) prevalensi anemia pada ibu hamil secara global mencapai $41.8 \%$ atau sekitar 56 juta ibu hamil. ${ }^{2}$ WHO menyebutkan bahwa 50\% anemia pada ibu hamil disebabkan karena defisiensi zat besi. ${ }^{3}$ Prevalensi anemia pada ibu hamil di Indonesia masih tergolong tinggi. Hal ini ditunjukkan oleh data dari World Bank 2005 bahwa 63\% ibu hamil di Indonesia mengidap anemia. ${ }^{4} \mathrm{Hal}$ itu diperkuat dengan data Riskesdas 2007 menunjukkan bahwa 24,5\% wanita usia subur menderita anemia pada saat kehamilannya. ${ }^{5}$ Prevalensi anemia di kota Semarang juga masih tergolong tinggi. Hal tersebut dibuktikan dari data Dinas Kesehatan Kota (DKK) Semarang tahun 2011 yang melaporkan bahwa sebanyak 17,93\% ibu hamil di Semarang menderita anemia. ${ }^{6}$

Anemia selama kehamilan dapat mengakibatkan kematian maternal, peningkatan angka kesakitan dan kematian janin serta peningkatan risiko bayi berat lahir rendah. ${ }^{7}$ Anemia selama kehamilan di Indonesia lebih banyak disebabkan karena defisiensi besi dan perdarahan akut atau merupakan interaksi keduanya. ${ }^{8}$ Selain itu, anemia juga dapat disebabkan karena defisiensi zat gizi lain yang memberikan kontribusi terhadap metabolisme zat besi di dalam tubuh seperti vitamin $\mathrm{A}$, vitamin $\mathrm{C}, \mathrm{B} 12$, asam folat, seng dan protein. ${ }^{9}$

Program suplementasi besi adalah salah satu program pemerintah di bidang kesehatan yang bertujuan untuk mengurangi dan mencegah anemia defisiensi besi terutama pada kehamilan. ${ }^{10}$ Program suplementasi besi seharusnya memiliki tingkat keberhasilan yang cukup tinggi mengingat tablet besi folat mudah diperoleh dan diberikan secara gratis. Namun, masih banyak ibu hamil yang tidak patuh mengkonsumsinya. Ketidakpatuhan tersebut disebabkan oleh beberapa hal diantaranya efek samping dari tablet yang mengganggu. Efek samping tersebut berupa gangguan seperti mual, muntah dan konstipasi yang timbul sesaat setelah mengkonsumsi tablet besi folat. Ketidakpatuhan tersebut sebenarnya juga merupakan salah satu dampak yang terjadi akibat ketidaktahuan mereka mengenai pentingnya asupan zat besi selama kehamilan. ${ }^{11,12}$ Selain itu faktor pengetahuan, motivasi, pelayanan kesehatan dan peran serta keluarga juga mempunyai andil yang cukup besar dalam mempengaruhi kepatuhan ibu hamil. ${ }^{11}$

Berdasarkan hal tersebut, penelitian ini bertujuan untuk menganalisis kepatuhan konsumsi tablet besi folat pada ibu hamil di Puskesmas
Halmahera dan faktor yang mempengaruhi.

\section{METODA}

Penelitian ini merupakan penelitian deskriptif analitik yang dilakukan dengan menggunakan desain cross-sectional yang dilakukan di Puskesmas Halmahera. Populasi target pada penelitian ini adalah semua ibu hamil di wilayah Semarang dan populasi terjangkaunya adalah ibu hamil di Puskesmas Halmahera. Jumlah subyek dalam penelitian ini adalah sebesar 56 orang ibu hamil yang memeriksakan diri di Puskesmas Halmahera. Pengambilan subyek dilakukan dengan menggunakan teknik consecutive sampling dengan kriteria ibu hamil trimester 2 dan 3 yang mendapatkan tablet besi folat dan dapat berkomunikasi dengan baik.

Variabel terikat dalam penelitian ini adalah kepatuhan konsumsi tablet besi folat. Kepatuhan mengkonsumsi tablet besi folat didefinisikan perilaku ibu hamil yang mentaati semua petunjuk yang dianjurkan oleh petugas kesehatan dalam mengkonsumsi tablet besi folat. Kepatuhan konsumsi tablet besi folat diperoleh melalui perhitungan tablet yang tersisa. Subyek dikategorikan patuh apabila angka kepatuhannya mencapai $90 \%$ dan dikategorikan tidak patuh apabila angka kepatuhannya $<90 \% .{ }^{13}$

Variabel bebas dalam penelitian ini terdiri dari pengetahuan, tingkat pendidikan, dukungan keluarga, dan kepuasan terhadap pelayanan kesehatan. Pengetahuan ibu hamil adalah pengetahuan mengenai tablet besi folat dan anemia defisiensi besi. Pengetahuan ibu hamil diukur dengan presentase skor jawaban benar pada kuesioner. Total skor pengetahuan adalah 13. Skor pengetahuan dikategorikan baik apabila $>80 \%$ jawaban benar, cukup bila jumlah jawaban benar antara $60-80 \%$ dan kurang jika $<60 \%{ }^{14}$

Pendidikan adalah jumlah tahun menyelesaikan sekolah yang diperoleh ibu hamil dalam pendidikan formal yang diikuti dan dinyatakan dalam tahun. Tingkat pendidikan ibu dikategorikan, sebagai berikut yakni: Tidak sekolah atau belum pernah sekolah, SD/MI, SMP/MTs, SMU/SMK, Akademi dan Universitas/Institut. ${ }^{15}$ Dukungan keluarga adalah peranan anggota keluarga atau suami yang dilakukan untuk meningkatkan kesehatan ibu hamil dapat berupa dorongan untuk melakukan ANC, pemberian informasi mengenai kehamilan dan anjuran untuk mengkonsumsi tablet. Dukungan keluarga diuji dengan menggunakan kuesioner yang terdiri dari 9 butir pertanyaan 
dengan jawaban "ya" dan "tidak". Kepuasan terhadap pelayanan kesehatan adalah kepuasan ibu hamil terhadap fasilitas pelayanan kesehatan (puskesmas) meliputi aspek fisik, pelayanan, dan sikap petugas kesehatan. Pelayanan kesehatan diukur melalui kuesioner yang menggunakan skala likert. Pelayanan kesehatan dianggap baik apabila lebih dari mean skor $\mathrm{T}$ dan dianggap kurang apabila jumlah skor kurang dari mean T. ${ }^{16}$

Normalitas data diuji dengan menggunakan uji Kolmogorov-Smirnov. Analisis bivariat dilakukan dengan menggunakan uji Rank Spearman karena data berdistribusi tidak normal.

\section{HASIL PENELITIAN}

Karakteristik responden

Tabel 1. Distribusi frekuensi karakteristik responden

\begin{tabular}{lcc}
\hline \multicolumn{1}{c}{ Karakteristik } & Frekuensi & Persentase (\%) \\
\hline Usia & 7 & $12,5 \%$ \\
a. $<20$ tahun & 35 & $62,5 \%$ \\
b. $20-30$ tahun & 14 & $25 \%$ \\
c. $>30$ tahun & 56 & $100 \%$ \\
\hline Total & & $42,9 \%$ \\
\hline Umur Kehamilan & 24 & $57,1 \%$ \\
\hline a. Trimester II & 32 & $100 \%$ \\
\hline b. Trimester III & 56 &
\end{tabular}

Berdasarkan tabel 1 dapat diketahui usia responden berkisar antara 18-38 tahun dan sebagian besar berusia antara 20-30 tahun $(62,5 \%)$. Selain itu, berdasarkan tabel 1 diketahui bahwa data usia kehamilan responden menunjukkan bahwa sebagian besar responden hamil trimester III $(57,1 \%)$ dan sisanya hamil trimester II dengan presentase $42,9 \%$.

\section{Kepatuhan responden dan variabel yang diteliti}

Tabel 2. Distribusi frekuensi berdasarkan variabel yang diteliti

\begin{tabular}{lcc}
\hline Variabel & Frekuensi & Presentase (\%) \\
\hline Kepatuhan & & \\
\hline Patuh & 23 & 41,1 \\
Tidak Patuh & 33 & 58,9 \\
\hline Pengetahuan & & \\
\hline Baik & 28 & 70 \\
Sedang & 4 & 4,1 \\
Kurang & 24 & \\
\hline Pendidikan & & 3,6 \\
\hline Tidak sekolah & 2 & 7,2 \\
SD & 4 & 14,3 \\
SMP & 8 & 71,5 \\
SMA/SMK & 40 & 1,8 \\
D1(Akademi) & 1 & 1,8 \\
S1 (Universitas) & 1 & \\
\hline Dukungan keluarga & 51,1 \\
\hline Baik & 5 & 8,9 \\
Kurang baik & 9 & 16,1 \\
\hline Kepuasan terhadap pelayanan kesehatan & 83,9 \\
\hline Baik & 47 & \\
Kurang & & \\
\hline
\end{tabular}


Berdasarkan data yang diperoleh selama penelitian, diketahui nilai rerata kepatuhan konsumsi tablet besi folat $70 \pm 33,01 \%$ dengan nilai terendah $0 \%$ dan tertinggi $100 \%$. Nilai rerata skor pengetahuan ibu hamil mengenai anemia dan tablet besi folat $80,76 \pm 14,11 \%$ dengan nilai terendah 38,46 dan tertinggi 100. Rerata tingkat pendidikan ibu hamil adalah $12 \pm 2,87 \%$ dengan nilai terendah 0 dan tertinggi 17. Nilai rerata dukungan keluarga adalah $8 \pm 1,53 \%$ dengan nilai terendah 3 dan tertinggi 9 . Data kepuasan terhadap pelayanan kesehatan menunjukkan rerata $47,49 \pm 10 \%$ dengan nilai terendah 39,14 dan tertinggi 91,77.

Hasil analisis univariat menunjukkan bahwa lebih dari setengah responden tidak patuh dalam mengkonsumsi tablet besi folat yaitu sebanyak 33 responden $(58,9 \%)$. Hasil skor pengetahuan yang diperoleh melalui kuesioner menunjukkan bahwa setengah dari jumlah responden berpengetahuan baik (50\%), namun dari data tersebut diketahui bahwa masih banyak responden yang berpengetahuan kurang $(42,9 \%)$. Data tingkat pendidikan responden menunjukkan bahwa pendidikan terakhir sebagian besar responden adalah SMA/SMK dengan jumlah 40 responden $(71,5 \%)$. Hasil skor dukungan keluarga yang diperoleh melalui wawancara dengan kuesioner menunjukkan bahwa sebagian besar responden $(91,1 \%)$ telah mendapatkan dukungan yang baik dari keluarganya. Hasil wawancara yang dilakukan dengan kuesioner mengenai kepuasan terhadap pelayanan kesehatan menunjukkan bahwa sebanyak 47 responden $(83,9 \%)$ merasa kurang puas terhadap pelayanan kesehatan yang ada.

\section{Alasan ketidakpatuhan}

Tabel 3. Distribusi frekuensi berdasarkan alasan ketidakpatuhan

\begin{tabular}{|c|c|c|c|c|c|c|}
\hline & Patuh & $\%$ & $\begin{array}{l}\text { Tidak } \\
\text { Patuh }\end{array}$ & $\%$ & $\begin{array}{l}\mathrm{N} \text { dari } \\
\text { total }\end{array}$ & $\begin{array}{l}\% \text { dari } \\
\text { Total }\end{array}$ \\
\hline \multicolumn{7}{|l|}{ Efek Samping } \\
\hline $\begin{array}{l}\text { Mual } \\
\text { Diare }\end{array}$ & 7 & $30,4 \%$ & 22 & $66,7 \%$ & 29 & $51,8 \%$ \\
\hline $\begin{array}{l}\text { Perubahan } \\
\text { warna tinja }\end{array}$ & 1 & $4,3 \%$ & 10 & $30,3 \%$ & 11 & $19,6 \%$ \\
\hline Konstipasi & 5 & $21,7 \%$ & 13 & $39,4 \%$ & 18 & $32,1 \%$ \\
\hline \multicolumn{7}{|l|}{$\begin{array}{l}\text { Alasan lain } \\
\text { ketidakpatuhan }\end{array}$} \\
\hline Bosan & 0 & $0 \%$ & 4 & $12,1 \%$ & 4 & $7,1 \%$ \\
\hline Lupa & 1 & $4,3 \%$ & 2 & $6,1 \%$ & 3 & $5,4 \%$ \\
\hline Fisiologis tablet & 7 & $30,4 \%$ & 20 & $60,6 \%$ & 27 & $48,2 \%$ \\
\hline Malas & 9 & $39,1 \%$ & 12 & $36,4 \%$ & 21 & $37,59 \%$ \\
\hline
\end{tabular}

Berdasarkan tabel 3 dapat diketahui beberapa alasan yang menyebabkan ketidakpatuhan. Alasan tersebut berupa efek samping tablet, bosan, lupa, fisiologis tablet dan rasa malas. Berdasarkan tabel dapat diketahui bahwa sebagian besar responden $(48,2 \%)$ merasakan bahwa tablet berbau amis dan efek samping yang dialami sebagian besar responden adalah mual $(51,8 \%)$.

\section{Distribusi responden berdasarkan media untuk mengkonsumsi tablet besi folat}

Tabel 4. Distribusi frekuensi berdasarkan media untuk mengkonsumsi tablet besi folat

\begin{tabular}{lllllll}
\hline $\begin{array}{l}\text { Media } \\
\text { konsumsi } \\
\text { tablet }\end{array}$ & Patuh & $\%$ & $\begin{array}{l}\text { Tidak } \\
\text { patuh }\end{array}$ & $\%$ & $\mathrm{~N}$ total & $\%$ \\
\hline The & - & - & 7 & $100 \%$ & 7 & $12,5 \%$ \\
Pisang & 3 & $33,3 \% \%$ & 6 & $66,7 \%$ & 9 & $16,1 \%$ \\
Susu & 1 & $100 \%$ & - & - & 1 & $1,8 \%$ \\
\hline
\end{tabular}




\begin{tabular}{lllllll}
\hline Air gula & - & - & 1 & $100 \%$ & 1 & $1,8 \%$ \\
Air putih & 19 & $50 \%$ & 19 & $50 \%$ & 38 & $67,8 \%$ \\
\hline
\end{tabular}

Berdasarkan tabel 4 dapat diketahui bahwa sebagian besar responden mengkonsumsi tablet dengan menggunakan air putih $(67,9 \%)$. Berdasarkan data yang ada pada tabel 4 terlihat bahwa sebagian besar responden yang mengkonsumsi tablet bersama teh dan pisang merupakan responden yang tidak patuh.

Hubungan antara pengetahuan, pendidikan. dukungan keluarga, dan kepuasan terhadap pelayanan kesehatan dengan Kepatuhan Mengkonsumsi Tablet Besi Folat



Diagram 1

Berdasarkan diagram 1 dapat diketahui hasil uji hubungan antara variabel pengetahuan dengan kepatuhan mengkonsumsi tablet besi folat menunjukkan adanya hubungan yang bermakna $(\mathrm{r}$ $=0,370 ; \mathrm{p}=0,005)$. Berdasarkan diagram 2 dapat

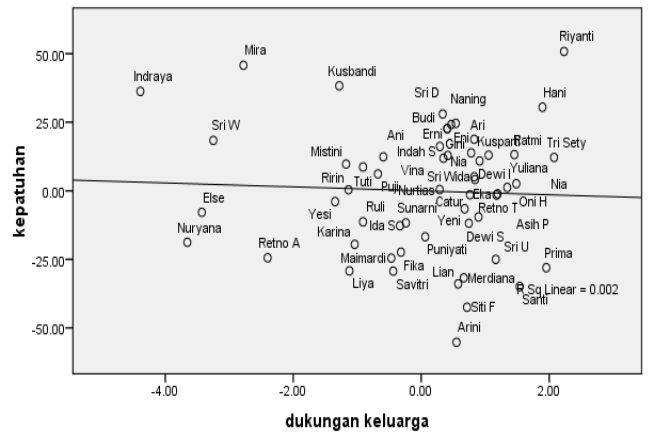

Diagram 3

Berdasarkan diagram 3 dapat diketahui hasil uji hubungan antara variabel dukungan keluarga dengan kepatuhan konsumsi tablet besi folat menunjukkan bahwa tidak ada hubungan yang bermakna $(\mathrm{r}=0,216 ; \mathrm{p}=0,115)$. Sedangkan diagram 4 menunjukkan bahwa hasil uji hubungan yang dilakukan antara variabel kepuasan terhadap pelayanan kesehatan dengan kepatuhan konsumsi tablet besi folat.menunjukkan bahwa tidak ada hubungan yang bermakna ( $r=0,217 ; p=0,108)$.

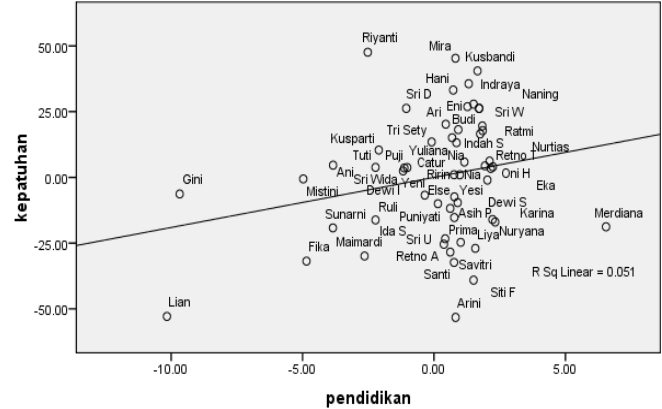

Diagram 2

diketahui hasil uji hubungan yang dilakukan antara antara variabel pendidikan dengan kepatuhan konsumsi tablet besi folat menunjukkan bahwa tidak ada hubungan yang bermakna $(r=0,032 ; p=$ $0,817)$.

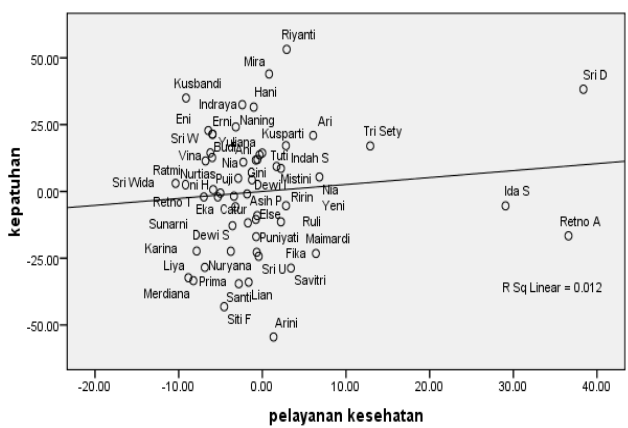

Diagram 4

\section{PEMBAHASAN}

Kepatuhan mengkonsumsi tablet besi folat dapat diartikan sebagai perilaku ibu hamil yang mentaati semua petunjuk yang dianjurkan oleh petugas kesehatan dalam mengkonsumsi tablet besi folat. Pada penelitian yang dilakukan di Puskesmas Halmahera ini, diperoleh hasil bahwa sebagian besar ibu hamil tidak patuh dalam mengkonsumsi tablet besi folat yaitu sebanyak 33 responden $(58,9 \%)$. Ketidakpatuhan ibu hamil di Puskesmas Halmahera disebabkan oleh beberapa hal antara lain karena lupa $(5,4 \%)$, kebosanan 
setelah mengkonsumsi tablet besi dalam kurun waktu yang lama $(7,1 \%)$ dan efek samping obat yang terasa mengganggu seperti mual $(51,8 \%)$, konstipasi $(32,1 \%)$ dan perubahan warna tinja $(19,6 \%)$. Hasil tersebut serupa dengan penelitian yang dilakukan oleh Purwaningsih yang menyebutkan bahwa faktor terbesar yang mempengaruhi tingkat kepatuhan ibu hamil dalam mengkonsumsi tablet besi folat adalah faktor lupa. ${ }^{17} \mathrm{Hal}$ ini diperkuat oleh penelitian yang dilakukan di Malaysia yang menyebutkan faktor lupa dan efek samping sebagai faktor utama yang menyebabkan rendahnya kepatuhan konsumsi tablet besi folat. ${ }^{18}$

Efek samping adalah efek tidak menyenangkan yang dirasakan ibu hamil setelah mengkonsumsi tablet besi folat. Penelitian yang dilakukan di Puskesmas Halmahera menunjukkan bahwa sebagian besar responden $(62,5 \%)$ merasakan adanya efek samping setelah mengkonsumsi tablet besi folat. Efek samping yang dialami oleh responden antara lain mual $(51,8 \%)$, perubahan warna tinja $(19,6 \%)$ dan konstipasi $(32,1 \%)$. Hal tersebut serupa dengan hasil penelitian yang dilakukan oleh Yekta yang melaporkan bahwa 30,3\% subyek dalam penelitiannya mengalami efek samping berupa mual setelah mengkonsumsi tablet besi folat dan menganggap efek tersebut sebagai masalah yang paling sering mengganggu kepatuhan. ${ }^{19}$ Efek samping yang dapat disebabkan oleh tablet besi folat antara lain mual, muntah, kram lambung, nyeri ulu hati dan konstipasi (terkadang juga terjadi diare). ${ }^{20}$ Selain efek samping yang dirasakan, sebagian besar ibu hamil juga merasakan bau dan rasa tablet besi folat yang diterima terasa amis $(48,2 \%)$. Oleh karena beberapa sebab tersebut, sebanyak $16,1 \%$ responden mengkonsumsinya dengan pisang, $12,5 \%$ responden mengkonsumsi dengan teh, 1,8\% responden mengkonsumsi dengan susu, 1,8\% responden mengkonsumsi dengan air gula dan sisanya dengan air putih. Efek samping yang ditimbulkan setelah mengkonsumsi tablet besi folat sebenarnya tidak berbahaya dan dapat dikurangi dengan mengkonsumsi tablet besi folat setelah makan malam sebelum tidur. ${ }^{18}$

Pengetahuan ibu hamil adalah pengetahuan mengenai tablet besi folat dan anemia defisiensi besi yang diperoleh dengan menggunakan kuesioner. Hasilnya, diketahui bahwa 50\% responden dapat menjawab dengan baik dari seluruh pertanyaan pengetahuan dan terdapat 24 responden $(42,9 \%)$ mempunyai pengetahuan dengan kategori sedang. Berdasarkan hasil uji hubungan yang dilakukan diketahui adanya hubungan yang bermakna antara pengetahuan dengan kepatuhan mengkonsumsi tablet besi folat $(\mathrm{r}=0,370 ; \mathrm{p}=0,005)$. Hal tersebut serupa dengan hasil penelitian yang dilakukan di Bantul yang menyebutkan bahwa ibu hamil yang memiliki pengetahuan mengenai anemia yang cukup baik belum dapat mendorong ibu hamil untuk lebih patuh mengkonsumsi tablet besi folat, akan tetapi terdapat kecenderungan bahwa sebagian besar ibu hamil yang patuh memiliki pengetahuan yang baik. Penelitian serupa yang dilakukan di RSUD Arifin Nu'mang menunjukkan bahwa pengetahuan ibu hamil yang baik mengenai tablet besi folat akan mempengaruhi kepatuhan ibu hamil dalam mengkonsumsi tablet. Pengetahuan ibu hamil ini tidak hanya diperoleh dari pendidikan formal tetapi juga dapat diperoleh melalui penyuluhan dan sosialisasi yang dilakukan oleh petugas kesehatan. $^{1}$

Berdasarkan data yang diperoleh selama penelitian di Puskesmas Halmahera diketahui bahwa sebagian besar responden di Puskesmas Halmahera berpendidikan SMA/SMK dengan jumlah 40 responden $(71,5 \%)$. Hasil uji hubungan yang dilakukan menunjukkan bahwa tidak ada hubungan yang bermakna antara pendidikan dengan kepatuhan konsumsi tablet besi $(\mathrm{r}=0,032$; $\mathrm{p}=0,817)$. Seharusnya, tingginya tingkat pendidikan ibu hamil dapat mendorong mereka untuk berperilaku positif termasuk dalam mengkonsumsi tablet besi folat. Namun, hasil uji hubungan yang dilakukan antara pendidikan dan kepatuhan konsumsi tablet besi folat menunjukkan bahwa tingginya tingkat pendidikan seseorang belum dapat mendorong seseorang untuk berperilaku sesuai dengan yang diharapkan. Hasil tersebut berbeda dengan penelitian yang dilakukan oleh Brand yang menyebutkan bahwa rendahnya kepatuhan lebih sering terjadi pada kelompok individu dengan pendidikan yang rendah. ${ }^{13}$ Penelitian yang dilakukan di Mangkang juga mencatat adanya hubungan positif antara ibu hamil yang berpendidikan rendah dengan kejadian anemia selama kehamilan. ${ }^{21}$

Berdasarkan data yang diperoleh selama penelitian di Puskesmas Halmahera diketahui terdapat 51 responden $(91,1 \%)$ yang mendapatkan dukungan yang baik oleh keluarganya. Seharusnya, adanya dukungan dari pihak keluarga dapat mendorong ibu hamil untuk lebih bersemangat dalam menghadapi perubahan-perubahan yang terjadi selama kehamilannya termasuk menjaga 
kesehatan kehamilannya melalui peningkatan kunjungan kehamilan dan konsumsi tablet besi folat. ${ }^{13}$ Namun, hasil uji hubungan antara dukungan keluarga dengan kepatuhan konsumsi tablet besi folat menunjukkan bahwa tidak ada hubungan yang bermakna $(r=0,216, p=0,115)$. Hal tersebut menunjukkan bahwa adanya dukungan yang diberikan oleh keluarga termasuk upaya untuk mengingatkan ibu hamil dalam mengkonsumsi tablet besi folat belum dapat mendorong ibu hamil untuk patuh mengkonsumsinya.

Data yang diperoleh selama penelitian mengenai pelayanan kesehatan diketahui bahwa terdapat 9 responden $(16,1 \%)$ yang berpendapat bahwa pelayanan kesehatan yang ada sudah baik dan 47 responden $(83,9 \%)$ merasa bahwa pelayanan kesehatan masih kurang. Pelayanan kesehatan masih dianggap kurang oleh ibu hamil karena banyak ibu hamil berpendapat bahwa fasilitas kesehatan yang ada di Puskesmas Halmahera masih kurang. Responden juga berpendapat bahwa terkadang diperlukan waktu yang lama untuk menunggu antrian. Kenyamanan selama berada di fasilitas pelayanan kesehatan sangat mempengaruhi kepuasan pasien dan merupakan salah satu faktor yang dapat mendorong pasien untuk datang berkunjung kembali. ${ }^{22}$ Meskipun sebagian besar responden merasa fasilitas yang ada masih kurang, namun mereka merasa bahwa mutu pelayanan yang diberikan cukup baik terutama peran petugas kesehatan dalam menganjurkan konsumsi tablet besi folat. Hasil uji menunjukkan bahwa hubungan antara pelayanan kesehatan dengan kepatuhan konsumsi tablet besi folat tidak bermakna ( $\mathrm{r}=$ $0,217, p=0,108)$. Hal tersebut menunjukkan bahwa mutu pelayanan kesehatan yang baik belum dapat mendorong ibu hamil untuk patuh mengkonsumsi tablet besi folat. Hasil tersebut berbeda dengan hasil penelitian yang dilakukan di RSUD Arifin Nu'mang yang menyebutkan bahwa pelayanan kesehatan termasuk petugas kesehatan akan mempengaruhi kepatuhan ibu hamil dalam mengkonsumsi tablet besi folat. ${ }^{12}$

\section{KETERBATASAN PENELITIAN}

Keterbatasan pada penelitian ini adalah masih kurangnya variabel penelitian yang ada sehingga belum diketahui variabel yang berhubungan kuat secara statistika dengan kepatuhan konsumsi tablet besi folat..

\section{SIMPULAN}

Lebih dari setengah jumlah responden $(58,9 \%)$ tidak patuh mengkonsumsi tablet besi folat. Pengetahuan ibu hamil menjadi faktor yang paling berpengaruh dibandingkan faktor yang lainnya (tingkat pendidikan, dukungan keluarga dan kepuasan terhadap pelayanan kesehatan).

\section{SARAN}

Sebaiknya untuk meningkatkan angka kepatuhan diperlukan upaya penyuluhan oleh petugas kesehatan mengenai pentingnya konsumsi tablet besi folat selama kehamilan dan efek samping yang ditimbulkan setelah mengkonsumsi tablet besi folat. Selain itu, masih diperlukan penelitian lebih lanjut dengan variabel yang lebih beragam dan dengan metode yang berbeda.

\section{DAFTAR PUSTAKA}

1. Arisman. Gizi dalam daur kehidupan. Jakarta: Penerbit Buku Kedokteran EGC: 2004

2. WHO. Worldwide prevalence of anaemia 1993-2005. WHO Global database on anemia. CDC Atlanta.WHO press; 2008

3. WHO. Iron deficiency anaemia: assessment, prevention, and control. A guide for programme managers. Geneva, World Health Organization, 2001

4. USAID. USAID/Indonesia nutrition assesment for 2010 new project design. Washington: USAID, 2010

5. Badan Perencanaan Pembangunan Nasional (BAPPENAS). Rencana Aksi Nasional Pangan dan Gizi (RANPG) 2011-2015

6. Dinas Kesehatan Kota. Kumpulan laporan program gizi Tahun 2011. DKK Semarang. 2011

7. Erick Miriam. Nutrition during pregnancy and lactation. In: L. Kathleen Mahan, Sylvia Escott-Stump. Krause's food and nutrition therapy. $12^{\text {th }}$ ed. Canada: Saunders Elsevier. 2008. Hal.175

8. Price, Sylvia A. Patofisiologi edisi 4. Jakarta: Penerbit Buku Kedokteran EGC; 2004. Hal: 256

9. Hertanto Wahyu Subagio. Anemia dan status gizi mikro pada ibu hamil. Mmed Indonesia; 40: 3. 2005. Hal: 134, 138

10. Older, Leslie K. Issues in programming for maternal anemia. Washington: Mothercare USAID 2000. Hal: 20

11. Schultink W; van der Ree M. Low compliance with an iron-supplementation program: a study among pregnant women in Jakarta, Indonesia. Am J Clin Nutr 1993; 57: 135-9

12. Muliaty. Faktor-faktor yang berhubungan dengan kepatuhan dalam mengkonsumsi tablet besi di RSUD Arifin Nu'mang Rappang Kabupaten Sidrap. Media Kesehatan 2009; 4: 1

13. Bongga DC, Ordenes MAC. Factors influencing 
compliance with iron supplementation among pregnant woment. Social Science Diliman 2006. 3; 84-107.

14. Ali Khomsan. Teknik pengukuran pengetahuan. Bogor: Institut Pertanian Bogor; 2000. Hal: 30-35

15. Departemen Kesehatan RI. Profil Kesehatan 2008. 2009. Hal: 6-12

16. Azwar S. Sikap manusia teori dan pengukurannya. Yogyakarta: Pustaka Pelajar; 2008. Hal: 3-7

17. Sri Purwaningsih, Marlia, Akhmadi. Analisis faktor-faktor yang mempengaruhi ketidakpatuhan ibu hamil dalam mengkonsumsi tablet besi. JIK Mei 2006; $01: 02$

18. S. Thirukkanesh, A.M. Zahara. Compliance to vitamin and mineral supplementation among pregnant women in urban and rural areas in Malaysia. Pakistan Journal of Nutrition 2010; 9(8):744-750

19. Yekta Z, Ayatollahi H, Pourali R, et al. Predicting factors in iron suplement intake among pregnant women in urban care setting. J Res Health Sci 2008; 8(1): 39-45.

20. Waterbury, Larry. Hematologi. Jakarta: EGC. 1998. Hal: 17

21. Irwan Budiono. Prevalensi dan determinan anemia pada ibu hamil di perkampungan nelayan. Jurnal KEMAS Januari- Juni 2009: 4:2

22. Imbalo SP. Jaminan mutu layanan kesehatan: dasar-dasar pengertian dan penerapan. Jakarta: EGC. 2007. Hal: 7-18 